\title{
Peran Kepemimpinan Kepala Madrasah dalam Meningkatkan Mutu Pendidikan Islam
}

\author{
Maryatin \\ Sekolah Tinggi Agama Islam Negeri (STAIN) Salatiga \\ Email: maryatin@gmail.com
}

\begin{abstract}
Abstrak
Artikel ini akan menjelaskan secara singkat peran kepemimpinan kepala madrasah dalam meningkatkan mutu pendidikan. Seorang pemimpin sekolah memiliki peran strategis untuk mewujudkan kualitas sekolah pendidikan. Lembaga ini membutuhkan pemimpin yang memiliki kemampuan dalam memimpin. Penggerak utama adalah tokoh dan inspirasi dalam merancang dan mengerjakan kegiatan di sekolah. Pemimpin bukan hanya seorang Manajer, dia juga harus menjadi pembangun mental, moral, semangat, dan kolektivitas untuk jajaran bawahannya dan tidak hanya menggunakan aturan tertulis, tetapi juga sikap perilakunya, figur, dan contoh dalam melakukan agenda transformasi kepemimpinan yang lebih baik. Pemimpin tidak harus dianggap sebagai objek eksploitasi, dengan demikian bawahannya harus dianggap sebagai teman dan mitra kerja. Jadi tidak ada kesewenangwenangan dan ketidakadilan. Karena tanpa bawahan pemimpin kurang berarti.
\end{abstract}

This article will briefly explain the role of the leadership of the head of school in improving education quality. A school leader has a strategic role to realize the school's quality of education. The institution needs a leader who has skills in leading. The principal mover is a figure and inspiration in designing and working on activities at the school. The leader is not just a Manager, he or she must also be a builder of mental, moral, spirit, and collectivity to his subordinates. He must not only use the written rules, but also the attitude of his behavior, image, and 
example in making a better leadership transformation agenda. The leader should not be regarded as an object of his exploits, thus his subordinates should be considered as friends and working partners. So there's no arbitrariness besides injustice. Leaders' role is meaningless without his subordinate.

Kata kunci: kepemimpinan, kualitas pendidikan, sekolah islam, madrasah

\section{Pendahuluan}

Kepala madrasah dalam proses pembelajaran memiliki peran yang sangat strategis serta mempunyai tanggung jawab yang berat untuk meningkatkan kualitas hasil belajar. Mengingat perannya yang sangat besar, keuletannya serta kewibawaannya dalam membuat langkahlangkah baru sebagai jawaban dari kebutuhan masyarakat. Dalam kepemimpinan tidak ada asas yang universal, yang nampak ialah proses kepemimpinan dan pola hubungan antar pemimpinnya. Fungsi utama kepemimpinan terletak dalam jenis khusus dari perwakilan.

Kepala madrasah adalah pemimpin tertinggi di sekolah. Pola kepemimpinannya akan sangat berpengaruh bahkan sangat menentukan kemajuan sekolah. Oleh karena itu dalam pendidikan modern kepemimpinan kepala seklah merupakan jabatan strategi dalam mencapai tujuan pendidikan.

Seorang pemimpin harus mewakili kelompoknya sendiri. Mewakili kelompoknya mengandung arti bahwa sipemimpin mewakili fungsi administrasi secara eksekutif. Ini meliputi koordinasi dan integrasi berbagai aktivitas, kristalisasi kebijaksanaan kelompok dan penilaian terhadap macam peristiwa yang baru terjadi dan membawakan fungsi 
kelompok. Selain itu seorang pemimpin juga merupakan perantara dari orang dalam kelompoknya di luar kelompoknya.

Berkenaan dengan kepemimpinan ini suatu kemampuan dan proses mempengaruhi ,mengkoordinir, dan mengendalikan orang lain yang ada hubungannya dengan pengembangan ilmu pengetahuan atau pendidikan serta agar kegiatan yang dilaksanakan lebih efisien dan efektif dalam pencapaian tujuan-tujuan pendidikan dan pengajaran. Bila diterapkan dalam organisasi Madrasah, ada tiga komponen yang berkaitan dengan budaya organisasi madrasah, yaitu: (1) institusi atau lembaga yang perannya dilakukan oleh kepala madrasah sebagai pemimpin organisasi madrasah, (2) guru-guru madrasah sebagai individu yang memiliki kepribadian dan kebutuhan, baik kebutuhan profesional maupun kebutuhan sosial, dan (3) interaksi dari kedua komponen tersebut. Untuk itu, kepala madrasah harus mampu mengintegrasikan kedua komponen tersebut, yakni peranan, tuntutan dan harapan lembaga, dengan kepribadian, dan kebutuhan guru, agar bisa mencapai tujuan organisasi secara optimal.

Studi keberhasilan kepala madrasah menunjukkan bahwa kepala madrasah adalah seseorang yang menentukan titik pusat dan irama suatu madrasah. Bahkan lebih jauh studi tersebut menyimpulkan bahwa keberhasilan madrasah adalah keberhasilan kepala madrasah. Beberapa diantaranya melukiskan kepala madrasah sebagai orang yang memiliki harapan itnggi bagi para staf dan para siswa, kepala madrasah mereka adalah yang mengetahui tugas-tugas mereka dan mereka yang menetukan irama bagi madrasah mereka. ( Wahjosumidjo, $202: 82$ ) 
Salah satu penentu keberhasilan madrasah terletak pada kepala madrasahnya. Terdapat hubungan biimplikasi antara keberhasilan kepala madrasah dengan madrasah itu sendiri. Seorang kepala madrasah dikatakan sukses melaksanakan tugasnya jika sekolah sukses menjalankan programnya ditambah dengan peningkatan prestasi di berbagai level. Begitupun sebaliknya madrasah akan mencapai prestasi yang baik apabila dipimpin oleh seorang kepala madrasah yang kompetensinya tinggi. Hal ini akan berdampak positif bagi keberlangsung kegiatan pembelajaran di madrasah tersebut. Implikasi lain yang akan diterima adalah tingkat kepercayaan masyarakat akan meningkat seiring dengan prestasi madrasah yang meningkat.

Dengan demikian keberhasilan madrasah banyak ditentukan keberhasilan kepala madrasah dalam menjalankan peranan dan tugasnya. Peranan adalah seperangkat sikap dan perilaku yang harus dilakukan sesuai dengan posisinya dalam organisasi. Peranan tidak hanya menunjukkan tugas dan hak, tapi juga mencerminkan tanggung jawab dan wewenang dalam organisasi. Ada banyak pandangan yang mengkaji tentang peranan kepala madrasah. Setidaknya ada tiga klasifikasi peranan kepala madrasah, yaitu: (1) peranan yang berkaitan dengan hubungan personal, mencakup kepala madrasah sebagai figure head atau simbol organisasi, leader atau pemimpin, dan liaison atau penghubung, (2) peranan yang berkaitan dengan informasi, mencakup kepala madrasah sebagai pemonitor, disseminator, dan spokesman yang menyebarkan informasi ke semua lingkungan organisasi, dan (3) peranan yang berkaitan dengan pengambilan keputusan, yang mencakup kepala 
madrasah sebagai entrepreneur, disturbance handler, penyedia segala sumber, dan negosiator. Tiga peranan ini menjadi pedoman seorang untuk menjadi pemimpin.

Peranan kepala madrasah dapat diklasifikasi menjadi dua, yaitu kepala madrasah sebagai administrator pendidikan dan sebagai supervisor pendidikan. Business manager, pengelola kantor, penguasa madrasah, organisator, pemimpin profesional, eksekutif yang baik, penggerak staf, petugas hubungan sekolah masyarakat, dan pemimpin masyarakat termasuk tugas kepala madrasah sebagai administrator madrasah. Dalam perannya sebagai administrator pendidikan, seorang pemimpin bertanggung jawab penuh atas jalannya roda administrasi dalam wilayah kepemimpinannya. Konsultan kurikulum, pendidik, psikolog dan supervisor merupakan tugas kepala madrasah sebagai supervisor pendidikan di madrasah. Dalam peranannya sebagai supervisor pendidikan, seorang pemimpin harus memastikan seluruh staff bekerja sesuai dengan job description yang telah disepakati sebelumnya

Keberhasilan kepala madrasah dalam melaksanakan tugasnya banyak ditentukan oleh gaya kepemimpinan seorang kepala madrasah. Kepemimpinan merupakan faktor yang paling penting dalam menunjang tercapainya tujuan organisasi madrasah. Keberhasilan kepala madrasah dalam mengelola kantor, mengelola sarana prasarana madrasah, membina guru, atau mengelola kegiatan madrasah lainnya banyak ditentukan oleh kepemimpinan kepala madrasah. Apabila kepala madrasah mampu menggerakkan, membimbing, dan mengarahkan anggota secara tepat, segala kegiatan yang ada dalam organisasi sekolah akan bisa terlaksana 
secara efektif. Sebaliknya, bila tidak bisa menggerakkan anggota secara efektif, tidak akan bisa mencapai tujuan secara optimal. Untuk memperoleh gambaran yang jelas, bagaimana peranan kepemimpinan dalam pengelolaan madrasah, maka perlu diuraikan tentang konsep dasar kepemimpinan kepala madrasah.

Penelitian penelitian tentang harapan peranan kepala madrasah sangat penting bagi guru-guru dan murid-murid. Pada umumnya kepala madrasah memiliki tanggung jawab sebagai pemimpin di bidang pengajaran, pengembangan kurikulum, administrasi kesiswaan, administrasi personalia staf, hubungan masyarakat, administrasi school plant, dan perlengkapan serta organisasi sekolah. Dalam memberdayakan masyarakat dan lingkungan sekitar, kepala madrasah merupakan kunci keberhasilan yang harus menaruh perhatian tentang apa yang terjadi pada peserta didik di sekolah dan apa yang dipikirkan orang tua dan masyarakat etntang sekolah. Cara kerja kepala madrasah dan cara ia memandang peranannya dipengaruhi oleh kepribadiannya, persiapan dan pengalaman profesionalnya, serta ketetapan yang dibuat oleh sekolah mengenai peranan sekolah di bidang pengajaran. Pelayanan pedidikan dalam dinas bagi administrator sekolah dapat memperjelas harapanharapan atas peranan kepala madrasah.

Berdasarkan rumusan hasil studi di atas menunjukkan betapa pentingp eranan kepala madrasah dalam menggerakkan kehidupan madrasah untuk mencapai tujuan yang telah disusun. Madrasah merupakan lembaga pendidikan yang memiliki ciri khusus keislaman, yang terkonsentrasi pada dua bidang keilmuaan yaitu ilmu pengetahuan 
umum dan ilmu pengetahuan agama. Tidak menutup kemungkinan bahwa madrasah akan mencakup wilayah yang lebih luas jika personel madrasah, terutama kepala madrasah, mampu mengoptimalkan potensi potensi yang tersedia. Masalah-masalah klasik, seperti permasalahan sarana dan prasarana, tentunya akan menjadi tantangan tersendiri bagi seorang kepala madrasah dalam perjalanan pengembangan madrasah.

Penelitian ini diharapkan mampu menambah khazanah ilmu pengetahuan yang berkaitan dengan pengelolaan lembaga pendidikan Islam pada umumnya, dan madrasah pada khususnya, serta iharapkan dapat memberi sumbang pemikiran berupa informasi atau pengetahuan bagi praktisi pendidikan di madrasah.

\section{Metode Penelitian}

Penelitian ini menggunakan metode penelitian deskriptif karena peneltian ini mempunyai tujuan untuk memperoleh jawaban yang terkait dengan pendapat, tangggapan atau persepsi seseorang sehinga pembahasannya dilakukan secara kualitatif. Model penelitian ini adalah library research. Library research adalah suatu riset kepustakaan. Pendekatan ini penulis gunakan untuk memperoleh data yang bersifat teoritis sebagai landasan teori ilmiah, yakni dengan cara memilih dan menganalisis literatur literatur yang relevan dengan judul atau permasalahan yang dikaji. 


\section{Kepemimpinan Kepala Madrasah}

Kepala madrasah merupakan salah satu komponen pendidikan yang paling berperan dalam meningkatkan kualitas pendidikan di madrasah untuk mencapai tujuan pembelajaran. Sebagaimana dikemukakan dalam Pasal 12 ayat 1 PP 28 tahun 1990 bahwa: "Kepala sekolah bertanggungjawab atas penyelenggaraan kegiatan pendidikan, administrasi sekolah. Namun kenyataannya masih banyak yang tidak memenuhi kriteria tersebut, karena tidak menjalankan tugas dan fungsinya sebagai penyelenggara pendidikan maupun administrasi sekolah dengan baik. Ada beberapa Kepala madrasah yang mempunyai mental yang kurang baik, hal ini ditandai antara lain kurangnya motivasi, semangat, kurang disiplin dalam melaksanakan tugas, sering datang terlambat, serta faktor penghambat lainnya yang dapat berakibat pada menurunkan kualitasnya lembaga pendidikan yang dipimpinnya.

Kepemimpinan merupakan salah satu faktor yang sangat penting dalam suatu organisasi karena sebagian besar keberhasilan dan kegagalan suatu organisasi ditentukan oleh kepemimpinan dalam organisasi tersebut. (Samsudin, 2006: 287) mengatakan bahwa: "Kepala madrasah dapat diartikan sebagai pemimpin madrasah/sekolah atau suatu lembaga yang menjadi tempat proses pembelajaran berlangsung (Wahjosumidjo, 2002 : 83) mengartikan Kepala madrasah adalah seorang tenaga fungsional guru yang diberi tugas untuk memimpin suatu sekolah di mana diselenggarakan proses belajar mengajar, tempat di mana terjadi interaksi antara guru yang memberi pelajaran dan murid yang menerima pelajaran. (Rahman 2006:106) mengungkapkan bahwa “Kepala madrasah 
adalah seorang guru (jabatan fungsional) yang diangkat untuk menduduki jabatan struktural (kepala madrasah) di sekolah. Berdasarkan definisi tersebut maka kepala madrasah adalah seorang guru yang mempunyai kemampuan untuk memimpin segala sumber daya yang ada di sekolah, sehingga dapat didayagunakan secara maksimal untuk mencapai tujuan bersama.

Jabatan Kepala madrasah menuntut suatu tanggung jawab yang sangat besar, oleh karena itu keprofesionalan adalah merupakan keniscayaan, sehingga kualitas yang tinggi dapat terwujud. Untuk itu Kepala madrasah harus mengetahui tugas-tugas yang harus ia laksanakan. Adapun tugas-tugas dari kepala madrasah menurut (Wahjosumidjo, 2002 : 97) adalah : (a) Kepala madrasah bekerja dengan dan melalui orang lain. Kepala madrasah berperilaku sebagai saluran komunikasi di lingkungan sekolah. (b) Kepala madrasah bertanggungjawab dan mempertanggung jawabkan. Ia bertindak dan bertanggungjawab atas segala tindakan yang dilakukan oleh bawahan. Perbuatan yang dilakukan oleh para guru, siswa, staf dan orang tua siswa tidak dapat dilepaskan dari tanggungjawabnya.

Dengan waktu dan sumber yang terbatas Kepala madrasah harus mampu menghadapi berbagai persoalan. Dengan segala keterbatasan kepala madrasah harus dapat mengatur pemberian tugas secara cepat serta dapat memprioritaskan apabila terjadi konflik antara kepentingan bawahan dan sekolah. (c) Kepala madrasah harus berfikir analitik dan konsepsional. Kepala madrasah harus dapat memecahkan persoalan melalui suatu analisis, kemudian menyelesaikan persoalan dengan satu 
solusi yang feasible, serta harus dapat melihat setiap tugas sebagai suatu yang saling berkaitan. (d) Kepala madrasah adalah seorang mediator dan juru penengah. (e) Kepala madrasah adalah seorang politisi. (f) Kepala madrasah adalah seorang diplomat. (g) Kepala madrasah adalah pengambil keputusan yang sulit. Selain tugas-tugas yang penting kepala madrasah juga harus memahami peranya, yang antara lain: (a) Peranan hubungan antar perseorangan. (b) Peranan informasional dan (c) Sebagai pengambil keputusan.

Selanjutnya peranan seorang pemimpin sebagaimana adalah sebagai berikut: (a) Sebagai pelaksana. (b) Sebagai perencana. (c) Sebagai seorang ahli. (d) Mewakili kelompok dalam tindakannya ke luar. (e) Mewakili hubungan antar anggota kelompok. (f) Bertindak sebagai pemberi gambaran/pujian atau hukuman. (g) Bertindak sebagai wasit dan penengah. (h) Merupakan bagian dari kelompok.(i) Merupakan lambang daripada kelompok. (j) Pemegang tanggung jawab para anggota kelompoknya.(k) Sebagai pencipta/memiliki cita-cita. (l) Bertindak sebagai seorang ayah. (m) Sebagai kambing hitam (Subagio, 2011 :1).

Selain peran di atas, fungsi kepala madrasah sebagai pemimpin menurut Koontz dalam Wahjosumidjo menyatakan bahwa agar para bawahan dengan penuh kemauan serta sesuai kemampuan secara maksimal berhasil mencapai tujuan organisasi, pemimpin harus mampu membujuk (to induce) dan meyakinkan (persuade) bawahan (Ma'mur, 2007: 105).

Apabila seorang kepala madrasah ingin berhasil menggerakkan para guru, staf, dan para siswa berperilaku dalam mencapai tujuan 
sekolah, maka kepala madrasah harus (a) Menghindarkan diri dari sikap dan perbuatan yang bersifat memaksa atau bertindak keras terhadap para guru, staf dan para siswa. (b) Sebaliknya kepala madrasah harus mampu melaksanakan perbuatan yang melahirkan kemauan untuk bekerja dengan penuh semangat dan percaya diri terhadap para guru, staf, dan siswa dengan cara meyakinkan (persuade), berusaha agar para guru, staf dan siswa percaya bahwa apa yang dilakukan adalah benar.dan membujuk (induce), berusaha meyakinkan para guru, staf dan siswa bahwa apa yang dikerjakan adalah benar.

Sedangkan peran kepala madrasah menurut H.G Hicks dan C.R. Gullet dalam Wahjosumidjo (2007: 106-109) ada delapan rangkaian peran kepemimpinan (leadership functions) yaitu, adil, memberikan sugesti, mendukung tercapainya tujuan, sebagai katalisator, menciptakan rasa aman, sebagai wakil organisasi,, sumber inspirasi, dan bersedia menghargai.

Sebagai pemimpin, kepala madrasah sebaiknya mempraktekkan kedelapan peran tersebut. Dalam kehidupan sehari-hari kepala madrasah akan dihapadapkan pada sikap para guru, staf dan siswa yang mempunyai latar belakang kehidupan, kepentingan, serta tingkat sosial budaya yang berbeda sehingga tidak mustahil terjadi konflik antar individu dalam kelompok, maka kepala madrasah harus bertindak arif, bijaksana, adil. Dengtan kata lain kepala madrasah harus dapat melakukan sama terhadap bawahannya, sehingga tidak ada diskriminasi sebaliknya dapat menciptakan rasa kebersamaan diantara mereka. 
Sugesti atau saran sangat diperlukan oleh para bawahan dalam melaksanakan tugas. Para guru, staf dan siswa hendaknya selalu mendapatkan saran dari kepala madrasah sehingga saran tersebut dapat memelihara atau meningkatkan semangat, rela berkorban, dan rasa kebersamaan dalam melaksanakan tugas masing-masing.

Dalam mencapai tujuan organisasi perlu dukungan dana, sarana dan sebagainya. Maka kepala madrasah harus bertanggung jawab untuk memenuhi dan menyediakan dukungan yang diperlukan para guru, staf dan siswa. Dalam melakukan tugas-tugasnya, kepala madrasah tidak bias menjalannkannya secara individu. Kepala madrasah membutuhkan guru, staf dan siswa dalam rangka melaksanakan program-program pembelajaran yang telah disusun di awal tahun ajaran. Oleh karena itu kepala madrasah harus menjaga hubungan yang baik dengan seluruh civitas akademik yang berada di wilayah kepemimpinannya. Hubungan yang baik ini akan memberikan efek sugestif, sehingga dalam melaksanakan tugas-tugasnya baik guru, staf maupun siswa melakukannya dengan penuh tanggung jawab.

Dalam era kemandirian madrasah dan era manajemen berbasis madrasah, kiranya pemahaman dan aplikasi konsep-konsep ilmu manajemen yang telah banyak dikembangkan oleh para pemikir di bidang bisnis perlu mendapatkan perhatian para pimpinan sekolah untuk memanajemen sekolah yang mereka pimpin di masa kini. Kesempatan untuk mengembangkan sebuah sekolah hingga menjadi sekolah yang efektif kiranya membutuhkan kreatifitas kepemimpinan yang memadai. Kepala madrasah harus mempunyai gagasan yang tinggi, dapat membuat 
terobosan-terobosan baru untuk mewujudkan pendidikan yang berkualitas dan berdaya saing. Dorongan/motivasi dari kepala madrasah juga harus diperhatika sehingga seluruh komponen pendidikan dapat berkembang secara profesional.

Dalam bingkai madrasah yang mandiri, kompetensi yang harus dimiliki kepala madrasah yaitu: memiliki landasan dan wawasan pendidikan; memahami sekolah sebagai sistem; merencanakan pengembangan sekolah; mengelola kurikulum; mengelola tenga pendidikan; mengelola sarana prasarana; mengelola kesiswaan; mengelola keuangan; mengelola hubungan sekolah dengan masyarakat; mengelola kelembagaan; mengelola sistem informasi sekolah; memimpin sekolah; mengembangkan budaya sekolah; memiliki dan melaksanakan kreativitas, inovasi dan jiwa kewirausahaan; mengembangkan diri; mengelola waktu; menyusun dan melaksanakan regulasi sekolah; memberdayakan sumberdaya sekolah; melakukan koordinasi/penyerasian; mengambil keputusan secara terampil; melakukan monitoring dan evaluasi; melaksanakan supervisi; menyiapkan, melaksanakan dan menindaklanjuti hasil akreditasi; dan membuat laporan akuntabilitas sekolah.

Kepala madrasah harus mampu berperan sebagai katalisator dalam arti mampu menimbulkan dan menggerakkan semangat para guru, staf dan siswa dalam pencapaian tujuan yang telah ditetapkan. Kepala madrasah juga harus mampu menciptakan rasa aman dalam lingkungan sekolah, sehingga para guru, staf dan siswa merasa aman dalam melaksanakan tugasnya dan bebas dari rasa gelisah karena ada jaminan 
rasa aman dari kepala madrasah. Peran kepala madrasah sebagai katalisator juga sangat dibutuhkan oleh sekolah dalam rangka mempercepat pencapaian tujuan sekolah dalam kurun waktu yang sudah ditentukan.

Kepala madrasah adalah sebagai pusat perhatian, maka penampilan seorang kepala madrasah harus selalu dijaga integritasnya, selalu terpercaya, dihormati baik sikap dan perilaku maupun perbuatannya. Kepala madrasah pada hakekatnya adalah sumber semangat bagi para guru, staf dan muridnya, sehingga mereka menerima dan memahami tujuan sekolah secara antusias, bekerja dan bertanggungjawab atas tujuan sekolah. Kepala madrasah hendaknya dapat menghargai apapun yang dihasilkan oleh para guru, staf dan siswa sebagai tanggungjawabnya. Penghargaan dan pengakuan kepala madrasah dapat diwujudkan dalam berbagai bentuk, sepserti kenaikan pangkat, fasilitas, kesempatan mengtikuti pendidikan dan sebagainya. Melalui langkah-langkah seperti ini, kepala madrasah akan menemukan cara kerja yang tepat untuk menggerakkan roda organisasi sekolah dalam rangka mempercepat pecapaian tujuan.

\section{Model Kepemimpinan}

Kepribadian pemimpin yang baik harus memiliki intelegensi yang baik, lapang dada dan memiliki kematangan sosial, memiliki motivasi instrinsik dan motivasi berprestasi, serta memiliki sikap yang baik dalam berhubungan secara manusiawi. Intelegensi yang baik sangat diperlukan seorang kepala madrasah. Intelegensi ini dibangun bertahun-tahun 
melalui suatu proses panjang jadi tidak serta merta hadir dalam diri seorang kepala madrasah. Sikap lapang dada diperlukan kaitannya dengan situasi kerja yang dinamis yang terdiri dari bermacam-macam karakter manusia. Dengan sikap lapang dada, pelaksanaan program madrasah akan berlangsung sesuai dengan rencana yang telah disusun. Sikap lapang dada ini merupakan implikasi dari kematangan sosial.

Motivasi dari dalam diri akan menimbulkan gairah kepemimpinan dalam diri seorang kepala madrasah. Menjadi kepala madrasah membutuhkan dorongan atau keinginan pribadi yang kuat untuk menjadi seorang kepala madrasah. Motivasi inilah yang menjadi modal dasar seorang mejalankan tugas sebagai kepala madrasah. Prestasi akan menjadi motivasi tambahan yang memperkuat citra baik seorang kepala madrasah.

Dalam rangka usaha untuk meningkatkan kepemimpinan, para manajer hendaknya mengenal bermacam-macam situasi dengan tujuan mendapatkan kesempatan melakukan komunikasi yang baik dalam rangka melakukan musyawarah dengan para bawahan. Proses ini akan membuka sekat-sekat sosial yang terjadi dalam suatu organisasi madrasah.

Sehubungan dengan usaha meningkatkan efektifitas kepemimpinan dengan menyesuaikan kebutuhan/motivasi para bawahan, kepala sekolah perlu menguasai gaya-gaya kepemimpinan. Beberapa gaya kepemimpinan, diantaranya model kepemimpinan eksklusif, otokratik, pembina, dan birokratik. Masing-masing memiliki kelebihan dan kekurangannya masing-masing. 
Model kepemimpinan eksklusif, yaitu pemimpin yang memperhatikan efektifitas, individualitas bawahan, dan kepentingan organisasi. Pemimpin ini bermotivasi tinggi, memperlakukan para bawahan dengan individualitasnya masing-masing, dan merupakan tim manager (kepemimpinan tim).

Model kepemimpinan otokratik yang bijaksana, yaitu pemimpin yang memperhatikan efektifitas dan kepentingan organisasi. Pemimpin ini paham betul dengan apa yang diinginkan dan giat mengejarnya.

Model kepemimpinan pembina/ pengembang yang menekankan efektifitas dan individu bawahan, pemimpin ini berusaha mengembangkan potensi setiap bawahannya.

Menurut Wahjosumijo (2007: 27-28) bahwa penting dikemukakan untuk meningkatkan kualitas pemimpin dengan empat faktor meliputi dimensi struktural, fasilitatif, suportif, dan partisipasif. Terdapat empat tipe kepemimpinan, yaitu kepemimpian structural, kepemimpinan fasilitatif, kepemimpinan suportif, dan kepemimpinan partisipatif.

Kepemimpinan Struktural. Kepemimpinan tipe ini memiliki ciriciri khusus sebagai berikut : cepat mengambil tindakan dalam waktu yang mendesak, melaksanakan pendelegasian yang jelas dan menentukan pada para anggota staf, menekankan kepada hasil dan tujuan organisasi, mengembangkan suatu pandangan organisasi yang kohesif sebagai dasar pengambilan keputusan, memantau penerapan keputusan, dan memperkuat relasi yang positif dengan pemerintah ataupun masyarakat setempat. Sudah seharusnya sebagai seorang kepala madrasah untuk 
mengembangkan sikap hidup sosial yang seluas-luasnya dan mempunyai kemampuan untuk berinteraksi dengan semua unsur masyarkat dan mampu memberikan pengertian atau pemahaman kepada masyarkat secara lengkap dan obyektif tentang madrasah yang dipimpinnya.

Kepemimpinan Fasilitatif. Indikasi dari kepemimpinan fasilitatif adalah sebagai berikut : mengusahakan dan menyediakan sumber-sumber yang diperlukan, menetapkan dan memperkuat kembali kebijakan organisasi, menekan atau memperkecil kertas kerja yang birokratis, memberikan saran atas masalah kerja yang terkait, membuat jadwal kegiatan, dan membantu pekerjaan agar dilaksanakan.

Kepemimpinan Suportif, yang mencakup: memberikan dorongan dan penghargaan atas usaha orang orang lain, menunjukkan keramahan dan kemampuan untuk melakukan pendekatan, mempercayai orang lain dengan pendelegasian tanggungjawab, memberikan ganjaran atas usaha perseorangan, dan meningkatkan moral/semangat staf.

Kepemimpinan Partisipasif, yaitu perilaku kepemimpinan yang menunjukkan tanda-tanda sebagai berikut: pendekatan akan berbagai persoalan dengan pikiran terbuka, mau atau bersedia memperbaiki posisiposisi yang telah terbentuk, mencari masukan dan nasehat yang menentukan, membantu perkembangan kepemimpinan yang posisional dan kepemimpinan yang sedang tumbuh, bekerja secara aktif dengan perseorangan atau kelompok, dan melibatkan orang lain secara tepat dalam pengambilan keputusan.

Kondisi Madrasah saat ini dihadapkan berbagai masalah diantaranya adalah kualitas hasil belajar, sulit mengejar prestasi yang 
seperti yang diraih oleh sekolah dasar umum lainnya. Untuk mengejar ketertinggalan tersebut, sementara yang lain masih terseok, tentunya tidak terlepas dari model kepemimpinan kepala madrasah dalam memimpin lembaganya. Adapun model atau gaya kepemimpinan yang sekarang ini berkembang.

Menurut Wahjosumidjo (2002: 97), kepemimpinan ada dua macam, kepemimpinan transaksional dan kepemimpinan transformasional. Kepemimpinan transaksional, model kepemimpinan ini digambarkan sebagai kepemimpinan yang memberikan penjelasan tentang apa yang menjadi tanggung jawab atau tugas bawahan dan imbalan yang dapat mereka harapkan jika mencapai standar tertentu. Gaya kepemimpinan ini akan terbuka dalam membagikan informasi dan tanggung jawab kepada bawahan. Hal ini memang merupakan komponen penting dalam menjalankan suatu organisasi, namun kepemimpinan ini tidak cukup untuk menerangkan usaha tambahan dan kinerja bawahan yang sebetulnya dapat digali seorang pemimpin dari karyawannya, oleh karena itu diperlukan konsep lain yang mampu menerangkan usaha bawahan yang lebih dari sekedar kesepakatan tugas dan imbalan antara pimpinan dan bawahan. Kepemimpinan transformasional, kepemimpinan ini digambarkan sebagai kepemimpinan yang membangkitkan atau motivasi karyawan untuk dapat berkembang dan mencapai kinerja atau tingkat yang lebih tinggi lagi sehingga mampu mencapai lebih dari yang mereka perkirakan sebelumnya (beyond expectation).

Hasil penelitian Chaudhry dan Javed menunjukkan ada persamaan dan sedikit perbedaan bahwa kepemimpinan transformasional memiliki 
hubungan positif, kuat dan signifikan dengan komitmen. Tapi tingkat motivasi dalam rasa hormat terhadap campur tangan pemerintah sangat rendah karena tidak adanya manajemen. Campur tangan pemerintah juga memiliki hubungan positif tapi karena tidak signifikannya hubungan itu mengindikasikan bahwa campur tangan pemerintah bukan merupakan model yang penting dan dorongan tingkat motivasi pekerja dibandingkan pada model kepemimpinan lain.

Menurut Siradj (2010) menyatkan bahwa pemimpin yang ideal di antaranya adalah 1) Al Kafa'ah yaitu pemimpin perlu memiliki sikap yang proporsional dalm berfikir, bersikap dan bertindak, 2) Al Ta'ahul yaitu pemimpin harus memiliki profesionalitas, 3) Al Infitah yaitu pemimpin harus punya sikap terbuka atau transparan dalam semua hal, 4) Al Ta'awun yaitu pemimpin harus sigap dalam soal memberikan pertolongan kepada umat dalam kemaslahatan bersama, 5) Al Ihsan yaitu pemimpin yang selalu bertindak dalam kebijakan yang baik dan demi kemaslahatan umat. 6) Al Mas'uliyah yaitu pemimpin yang selalu bertanggung jawab, memiliki sikap liabilitas dan akuntabilitas tinggi kiranya yang perlu diperhatikan soal kepemimpinan adalah lebih pada persoalan moralitas.

\section{Urgensi Kepemimpinan Pendidikan}

Sebuah lembaga pendidikan membutuhkan seorang pemimpin. Sebab pemimpin adalah sebagai sosok penggerak dan inspirasi dalam merancang dan mengerjakan kegiatan. Pemimpin tidak hanya seorang manajer, ia juga harus seorang pembangun mental, moral, spirit, dan 
kolektivitas kepada jajaran bawahannya. Seorang pemimpin seyogyanya tidak hanya menggunakan aturan tertulis, tapi juga sikap perilaku, sepak terjang, dan keteladanan dalam melakukan agenda transformasi kepemimpinan yang lebih baik. Pemimpin harus bisa menunjukkan figur atau sosok yang mendekati sempurna karena akan menjadi contoh bagi bawahan.

Seorang kepala madrasah harus dapat mempunyai kompetensi untuk mengelola segala sumber daya yang dimiliki oleh madrasah secara maksimal agar dapat ,encapai tujuan madrasah, karena sumber daya yang dimiliki madrasah merupakan modal dasar dan penentu keberhasilan mencapai tujuan madrasah (Saroni, 2006: 48). Dengan demikian kepala madrasah sebagai seorang pemimpin pendidikan memerlukan suatu kepemimpinan yang efektif dan efisien. Kepemimpinan yang efektif dan efisien ini akan menjadi motor penggerak dan penentu arah kebijakan madrasah. Hal ini akan menentu bagaiman tujuan-tujuan madrasah direalisasikan.

Pemimpin tidak boleh menganggap bawahannya sebagai objek eksploitasi, justru sebaiknya bawahannya dianggap sebagai teman dan mkitra kerja. Jadi tidak ada kesewenang-wenangan, kezdaliman, dan ketidakadilan. Karena tanpa bawahan pemimpin tidak ada artinya. Menurut Ma'mur (2009: 92) pada hakekatnya pemimpin adalah seorang yang mempunyai kemampuan untuk mempengaruhi perilaku orang lain dalam kerjanya dengan menggunakan kekuasaan. Pemimpin harus bias mengkondisikan dirinya dalam setiap keadaan. Tipe-tipe kepemimpinan memiliki keunggulan dan kelemahan masing-masing. Tipe 
kepemimpinan yang sangat cocok untuk suatu keadaan belum tentu cocok untuk kondisi lainnya. Jika digunakan pada waktu dan tempat yang tepat maka roda organisasi akan berjalan baik.

Pada hakekatnya seorang pemimpin adalah seseorang yang mempunyai kemampuan untuk mempengaruhi perilaku orang lain di dalam kerjanya dengan menggunakan kekuasaan. Semakin banyak sumber kekuasaan yang tersedia bagi pemimpin, akan semakin besar potensi kepemimpinan yang efektif. Adapun jenis kepemimpinan ada bermacam-macam, ada pemimpin formal (terjadi karena pemimpin bersandar pada wewenang formal) dan ada pemimpin informal(terjadi karena pemimpin tanpa wewenang formal berhasil mempengaruhi perilaku orang lain).

Faktor-faktor yang mempengaruhi kepemimpinan kepala madrasah antara lain: (a) Kepribadian (personality), pengalaman masa lalu, dan harapan pemimpin. Hal ini mencakup nilai-nilai, latar belakang, dan pengalamannya. (b) Harapan dan perilaku atasan. (c) Karakteristik, harapan, dan perilaku bawahan. (d) Kebutuhan tugas. (e) Iklim dan kebijaksanaan organisasi. (f) Harapan dan perilaku rekan. Faktor-faktor tersebut akan mempengaruhi kesuksesan pemimpin dalam aktivitasnya yang tentunya ditunjang oleh hubungan keharmonisan dengan bawahan, latar belakang pemimpin baik pendidikan maupun sosial, motivasi untuk berprestasi, kedewasaan, sikap dan keleluasaan dalam hubungan sosial.

Di samping faktor-faktor yang mempengaruhi kepemimpinan, ada berbagai pendekatan dalam memecahkan masalah kepemimpinan (Fatah, 2008: 88) yang dapat dilakukan. Antara lain pertama, dengan pendekatan 
sifat yang memfokuskan pada karakteristik pribadi pemimpin. Pendekatan kedua, yaitu pendekatan perilaku dalam hubungannya dengan bawahannya. Pendekatan ketiga, yaitu pendekatan situasional yang memfokuskan pada kesesuaian antara perilaku pemimpin dengan karakteristik situasional. Pandangan situasi mengasumsikan bahwa kondisi yang menentukan efetifitas kepemimpinan bervariasi menurut situasi, ketrampilan dan harapan bawahan, lingkungan organisasi serta pengalaman masa lalu pemimpin dan bawahan.

Berdasar kajian teori tersebut dapat dibuat kerangka berfikir bahwa model kepemimpinan Kepala madrasah yang baik sangat diperlukan dalam menggerakkan seluruh komponen yang ada di madrasah baik guru, siswa, karyawan untuk saling bahu membahu dalam mengembangkan madrasah menjadi lebih berkualitas. Apabila kualitas madrasah meningkat, maka citra Madrasah akan menjadi baik dan masyarakatpun akan melirik Madrasah Ibtidaiyah sebagai lembaga pendidikan yang tidak boleh dianggap remeh.

Lebih penting lagi apabila dalam mengembangkan dan meningkatkan kualitas kepemimpinan lembaga pendidikan sebagai entry point, seorang pemimpin/ kepala madrasah memperhatikan prinsipprinsip visi progresif, manajemen fungsional, konsolidasi internal, profesionalisme, transparansi keuangan, antisipatif, diversifikasi, dan menerapkan high technology.

Visi progresif, pandangan, pemikiran dan filosofi yang jauh ke depan dalam menetapkan tujuan. Manajemen fungsional, menerjemahkan visi dalam bentuk program dan kegiatan yang terukur secara sistematis, 
dan efektif dengan kekuatan struktur yang kuat. Konsolidasi internal, menyatukan semua kekuatan yang ada untuk bergerak secara kolektif dalam mencapai tujuan yang disepakati. Profesionalisme, melaksanakan sesuatu secara profesionalisme, sesuai dengan kemampuan, sesuai dengan job description yang ada, sesuai dengan kewenangannya, dan sesuai dengan bidamng garapannya. Transparansi keuangan, mengembangkan network relationship; mengembangkan relasi dan bekerja sama dan ini memerlukan ilmu, pengalaman, dan bantuan lembaga lain, dan begitu sebaliknya.

Antisipatif; kemajuan ilmu pengetahuan dan teknologi akan berimbas pada semua aspek, hal ini menimbulkan tantangan yang berat yang harus direspon insan pendidikan. Lembaga yang pasif mengamtisipasi tantangan masa depan, akan menjadi lembaga yang miskin prestasi, semakin tertinggal dan terancam gulung tikar. Untuk menghindari hal tersebut, sikap antisipatif menjadi penting dalam rangka menjaga image madrasah yang sudah terbangun sebelumnya ataupun membangun image madrasah menjadi lebih baik.

Diversifikasi, pengembangan satu unit menjadi beberapa unit agar masing-masing unit fokus pada bidangnya sendiri-sendiri dalam mengembangkan diri dan merespon berbagai tantangan yang ada. Dengan demikian semua elemen akan bekerja pada bidang-bidang yang sudah menjadi tanggung jawabnya. Ini bukan berarti bidang lain tidak boleh membantu bidang yang lain, namun setiap bidang focus terlebih dahulu terhadap tugas-tugasnya baru kemudian memberikan bantuan bidang yang lain. 
Menerapkan high technology, kemajuan teknologi menjadi tantangan pendidikan, maka sudah waktunya penggunaan teknologi dimanfaatka secara optimal untuk menangkap informasi, mengembangkan penelitian, dan beradaptasi dengan era informasi yang berkembang cepat. Era teknologi saat ini sudah memberikan dampak luar biasa terhadap arus informasi. Dalam waktu sekian detik, suatu informasi sudah dapat tersebar dengan sangat luas. Semua orang tidak perlu susahsusah untuk mendapatkan suatu informasi jika dia sudah menguasai teknologi. Dengan demikian, kepala madrasah harus menggunakan teknologi untuk memperoleh maupun menyebarkan informasi. Jika tidak demikian, maka madrasah akan terlambat mendapatkan informasi.

Fokus pembidangan, pemimpin perlu memberikan trade mark bagi lembaga pendidikan yang dipimpinnya, dengan trade mark lembaga pendidikan dapat fokus dalam program dan kegiatannya, baik dalam jangka pendek, menengah dan jangka panjang. Trade mark ini bisa terwujud melalui visi misi yang jelas dan konkrit, bukan hanya sebuah retorika demi gugurnya syarat mendirikan suatu organisasi. Visi dan misi yang ada harus menjadi landasan dan tujuan bersama seluruh elemen madrasah.

Pemberdayaan masyarakat, lembaga pendidikan yang terasing dari komunitas sosial, akan banyak menghadapi masalah yang mengganggu dinamika pendidikan. Seorang kepala madrasah harus jeli memberdayakan masyarakat sebagai wahana mengembangkan kualitas anak didik. Regenerasi adalah salah satu langkah antisipasi yang cerdas, dan merupakan investasi sumber daya manusia yang tidak pernah habis 
dengan menyiapkan kader-kader terbaiknya untuk menggantikannya. Jika prinsip ini benar dilaksanakan oleh seorang kepala madrasah, maka madrasah akan semakin cepat mencapai tujuan bersama.

Pemaparan sebelumnya sudah sangat jelas bahwa iklim madrasah sangat bergantung pada kepemimpinan kepala madrasah. Hasil penelitian Goleman (2002: 44) menyimpulkan bahwa IQ hanya memberikan kontribusi setinggi-tingginya $20 \%$ terhadap keberhasilan seseorang, sedangkan sekitar $80 \%$ dipengaruhi oleh faktor lain. Dengan memiliki pribadi yang baik, kepala madrasah sudah mempunyai modal untuk meningkatkan kompetensi. Dengan porsi yang hanya $20 \%$ tadi, tentu kepala madrasah harus selalu melakukan peningkatan komptensi (upgrading) agar semakin kompeten dan professional dalam mengelola sebuah madrasah.

Kepala madrasah yang profesional sangat diperlukan dalam pengembangan madrasah. Dalam paradigma modern, kepala madrasah semakin menjadi sentral dan harus memberikan dampak positif dan perubahan yang cukup mendasar dalam pembaharuan sistem pendidikan di madrasah yang dipimpin. Dampak tersebut antara lain terhadap efektifitas pembelajaran, kepemimpinan sekolah yang kuat, pengelolaan tenaga pendidikan yang efektif, budaya mutu, teamwork yang kompak, cerdas dan dinamis, kemandirian, partisipasi warga sekolah dan masyarakat, keterbukaan (transparansi) manajemen, kemauan untuk berubah (psikologis dan fisik), evaluasi dan perbaikan berkelanjutan, responsive dan antisipatif terhadap kebutuhan, akuntabilitas, dan sustainabilitas. 


\section{Kesimpulan}

Peran strategis kepala madrasah menjadi bagian dari kualitas hasil belajar dan kepemimpinan kepala Madrasah Ibtidaiyah yang ideal seharusnya lebih menekankan pada kepemimpinan partisipatif yang eksklusif dan supportif antara lain dengan menerapkan manajemen yang terbuka dan dapat dipertanggungjawabkan secara akuntabel terhadap stake holders.

Sedangkan faktor yang mempengaruhi model kepemimpinan kepala Madrasah Ibtidaiyah adalah kepribadian (personality), pengalaman masa lalu, dan harapan pemimpin. Hal ini mencakup nilainilai, latar belakang, dan pengalamannya, harapan dan perilaku sebagai atasan, karakteristik, harapan, dan perilaku bawahan, dan kebutuhan tugas, serta iklim dan kebijaksanaan organisasi, juga harapan dan perilaku rekan. Dampak model kepemimpinan kepala madrasah terhadap perkembangan Madrasah Ibtidaiyah bahwa kepala madrasah memiliki kepribadian yang cocok melaksanakan tugas memimpin, beliau juga memperhitungkan faktor situasi dalam melaksanakan kepemimpinan, demikian pula selalu melakukan transaksi antara dia sebagai pemimpin dengan orang-orang yang dipimpin, yaitu mengusahakan suatu kesepakatan bersama dalam memajukan kualitas madrasah.

Madrasah perlu juga membina hubungan yang baik serta harmonis dengan masyarakat sekitar madrasah, yang secara langsung maupun tidak langsung dapat menunjang kegiatan pembelajaran seperti tokoh masyarakat, pejabat pemerintah dan lain-lain. 


\section{Daftar Pustaka}

Chaudhry, Abdul Qayyun \& Javed, Husnain 2009-11." Impact of Transactional and Laissez Faire Leadership Style of Motivation", International Juornal of Busines and Social Science, University of The Punjab, Pakistan, Vol.3, No.7, 2012.

Fattah, Nanang. 2008. Landasan Manajemen Pendidikan. Bandung: Remaja Rosdakarya.

Goleman, D. \& Boyatzis, R. 2002. Kepemimpinan Berdasarkan Kecerdasan Emosi. Terjemahan oleh Susi Purwoko. Jakarta: Gramdia Pustaka Utama.

Ma'mur, Jamal Asmani. 2007. Manajemen Pengelolaan dan Kepemimpinan Pendidikan Profesional Panduan Quality Control Bagi Para Pelaku Pendidikan. Yogyakarta: DIVA Press.

Rahman et. all. 2006. Peran Strategis Kepala madrasah dalam Meningkatkan Mutu Pendidikan. Jatinangor: Alqaprint.

Samsudin, S. 2006. Manajemen: a Guide to Executive Command. Bandung: CV Pustaka Setia.

Saroni, Muhamad. 2006. Manajemen Madrasah. Yogyakarta: Ar Russ.

Siradj, Said Aqiel, MA. 2010. "Pemimpin Yang Maslahah Bagi Muhammadiyah",

MAARIF Institut. Vol. 5, No.1, Juni 2010, Hlm.87-93

Wahjosumidjo. 2002. Kepemimpinan Kepala Sekolah. Jakarta: PT Raja Grafindo. 